\title{
ПРАВОВЫЕ ПРОБЛЕМЫ ИНДЕКСАЦИИ ЗАРАБОТНОЙ ПЛАТЫ
}

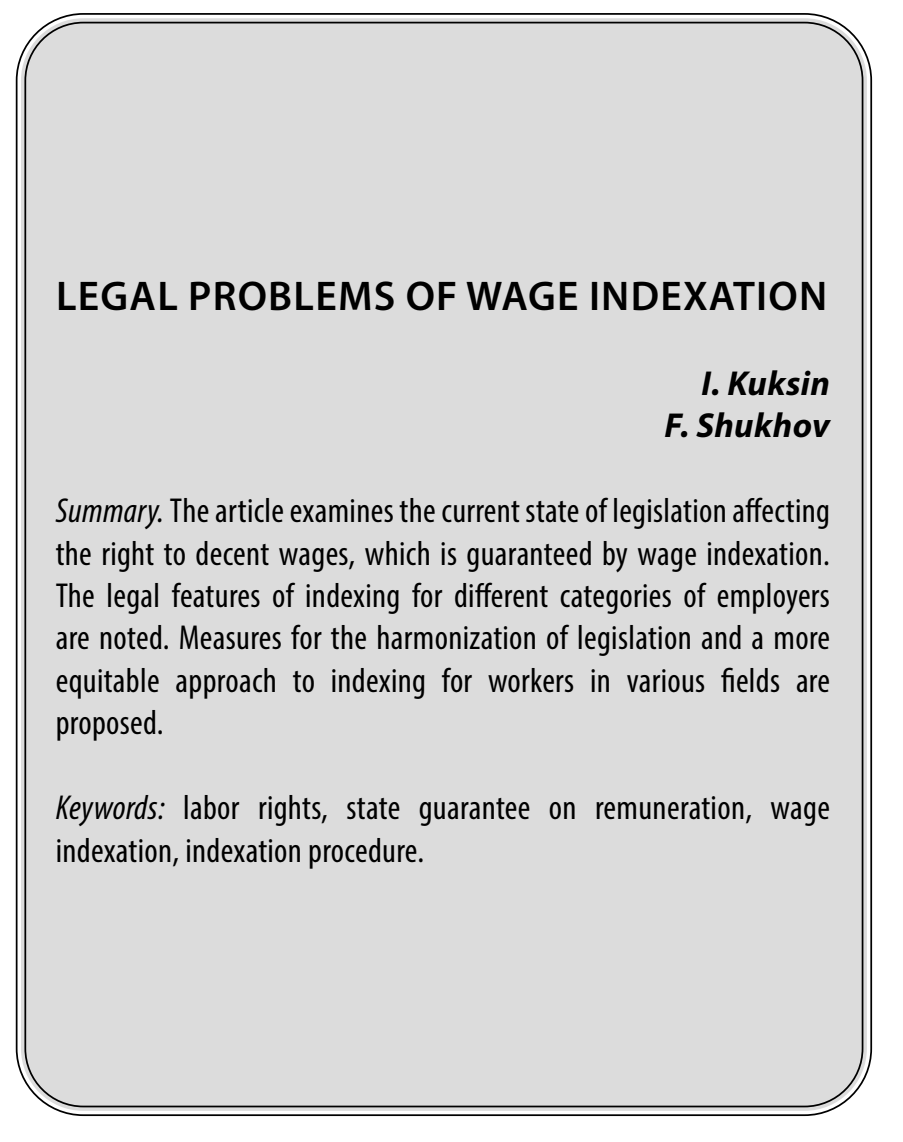

Summary. The article examines the current state of legislation affecting the right to decent wages, which is guaranteed by wage indexation. The legal features of indexing for different categories of employers are noted. Measures for the harmonization of legislation and a more equitable approach to indexing for workers in various fields are

Keywords: labor rights, state guarantee on remuneration, wage indexation, indexation procedure.

овокупность трудовых прав россиян базируется на праве на свободный труд, провозглашенном в ст. 37 Конституции Российской Федерации. Что касается вознаграждения за труд, то Конституция гарантирует его получение без дискриминации по тому или иному признаку и в объеме не меньшем, чем минимальный размер оплаты труда (МРОТ). Однако Всеобщая декларация прав человека (1948 г.) гласит и, вслед за ней ст. 2 ТК РФ, что справедливое и удовлетворительное вознаграждение должно обеспечивать достойное существование для него самого и его семьи. Очевидно, что МРОТ в России, который с1 января 2021 года составляет 12792 рубля (ст. 1 Федерального закона от 19.06.2000 N82-Ф3) не может обеспечить достойное существование ни самому работнику, ни его семье, при том, что в 58 регионах, он остался на уровне федерального [8]. Следует отметить, что стоимость минимального набора продуктов питания по России на август 2021 года составляет 4870 рублей (в январе - 4096 рублей) [9], а стоимость фиксированного набора потребительских товаров и услуг в августе 18106 рублей 25 копеек (в январе - 16284 рубля 89 копеек) [10]. Инфляция же к августу 2021 года составила 6,7\% [1].

\author{
Куксин Иван Николаевич \\ Д.ю.н., профессор, Московский городской \\ педагогический университет \\ proffkuk-1944@yandex.ua \\ Шухов Федор Гелиевич
}

К.ю.н., старший преподаватель, Петербургский государственный университет путей сообщения Императора Александра I fedor.ru@bk.ru

Аннотация. В статье рассмотрено современное положение законодательства, затрагивающее право на достойную оплату труда, которое гарантировано индексацией заработной платы. Отмечены правовые особенности индексации для разных категорий работодателей. Предложены меры для гармонизации законодательства и более справедливого подхода к индексации для работников различных сфер.

Ключевые слова: трудовые права, государственная гарантия по оплате труда, индексация заработной платы, порядок индексации.

Стремление законодателя приблизить оплату труда к некоему справедливому значению в связи с ростом потребительских цен на товары и услуги выражено в ст. 134 Трудового Кодекса Российской Федерации, согласно которому работодатели обеспечивают повышение уровня реального содержания заработной платы путем ее индексации. Государственные органы, органы местного самоуправления, государственные и муниципальные учреждения производят ее в установленном трудовым законодательством порядке, а другие работодатели - в соответствии с локальными нормативными актами, коллективным договором, соглашениями.

В этом отношении судьба зарплат работников бюджетной сферы наиболее предсказуема. В проекте федерального бюджета на 2022 год указаны размеры индексации заработной платы работников федеральных государственных учреждений и денежного содержания федеральных государственных служащих в 2022, 2023 и 2024 году [3]. Для чиновников, например, она составит по 4\% ежегодно. При этом в 2021 году индексация не проводилась из-за стремления сбалансировать бюджет в сложной экономической ситуации, также индек- 
сации не было в 2014, 2015 и 2016 годах также в связи с кризисом. Таким образом, можно говорить о том, что хотя индексация и числится среди гарантий трудового законодательства, но в случае с работниками бюджетной сферы ее наличие и размер зависят от экономических показателей.

Что касается индексации зарплат работников других сфер, то федеральное законодательство не дает больших пояснений, чем содержится в рамочной ст. 134 ТК РФ. Конституционный суд в своем определении от 19.11.2015 N2618-О установил, что работодатели, не относящиеся к бюджетной сфере, не могут лишать работников установленной гарантии индексации, и должны предусмотреть эту меру в собственных локальных актах [5], т.е. отсутствие конкретизирующего законодательства не является препятствием для выполнения этого обязательства и не нарушает права работников других сфер, т.к. является ответственностью конкретного работодателя.

При этом позиция Верховного Суда подверглась некоторым изменениям. Так, в 2017 году суд указал, что индексация - не единственный способ повышения размера содержания заработной платы, а один из возможных, т.е. работодатель может увеличивать ее размер путем повышения должностных окладов, выплаты премий, безотносительно порядка индексации, что будет мерой повышения реального содержания заработной платы [4]. В 2019 же году Верховный Суд постановил, что если в локальных нормативных актах или коллективном договоре содержится гарантия повышения реального содержания заработной платы в форме индексации, то она должна производится независимо от применения других видов повышения заработной платы [6]. При этом в определениях обозначено, что рамочный характер ст. 134 ТК РФ позволяет учитывать всю совокупность обстоятельств индексации зарплаты, значимых как для работника, так и для работодателя, что соответствует правому положению работодателей, не относящихся к бюджетной сфере.

Отсутствие обязательной индексации зарплаты влечет административную ответственность (ч. 1, 2 ст. 5.27 КоАП РФ), дисциплинарную ответственность представителя работодателя, проведение прокурорской проверки, проведение контрольных мероприятий Федеральной инспекцией труда.

Между тем обилие судебной практики по вопросам соблюдения обязанности работодателя по индексации заработной платы указывает на то, что свобода, предоставленная законодателем, используется для избегания индексации, а не для ее наиболее эффективного для всех сторон трудовых отношений осуществления.
В этой связи в Государственную Думу в сентябре 2021 года внесен законопроект «О внесении изменений в статью 134 Трудового кодекса Российской Федерации (в части обязательств работодателей по индексации заработной платы работников)» [2]. В нем предложены условия индексации и ее механизм для работодателей не из бюджетной сферы:получение прибыли по итогам финансового года; отсутствие признаков несостоятельности (банкротства); проведение индексации не реже одного раза в год, не позднее 4 месяцев с момента окончания финансового года. В законопроекте также содержится норма, определяющая размер индексации при его отсутствии во внутренних документах компании - в соответствии с индексом потребительских цен в регионе. В данный момент проходит предварительное рассмотрение законопроекта.

Законопроект не лишен ряда недостатков. На наш взгляд, такие предложенные условия и механизм может быть использован в случае, если работодатель самостоятельно не установил порядок индексации. Такая норма будет способствовать не только дополнительной гарантии осуществления права на индексацию зарплаты, но и вдохновит работодателей на нормотворчество в рамках своей организации, т.к. существующая редакция статьи оставляет широкий выбор, предписывая только обязательность индексации и ее закрепления во внутренних документах.

Кроме того, в список ориентиров для размера индексации могут быть включены следующие показатели: прогнозируемый уровень инфляции в РФ, изменение величины прожиточного минимума в регионе, соответствие значениям индексации, установленным в отраслевых соглашениях. Также дополнительно должно быть разъяснено отличие индексации от другого типа повышения зарплат через введение определения понятия «индексация заработной платы». Также подлежит закреплению в ст. 21 и ст. 22 ТК РФ право работника на индексацию заработной платы и обязанность работодателя проводить индексацию. Кроме того, звучат и предложения внести изменения в ст. 39 Конституции РФ, добавив туда гарантию индексации заработной платы [7], что на наш взгляд, является все же излишним.

Следует констатировать, что на сегодняшний момент, индексация заработной платы, хотя и предписана законодательством, но в большой степени зависит от добросовестности работодателя и его финансового положения, что ставит многих работников внебюджетной сферы в более уязвимое положение. Для наиболее полной реализации права на справедливую оплату труда законодателю необходимо внести изменения в действующее трудовое законодательство и закрепить право работников на индексацию заработной платы, что особенно актуально в существующих сложных экономических условиях. 
ЛИТЕРАТУРА

1. Банк России. Ключевые показатели. URL: https://cbr.ru/key-indicators/(дата обращения: 10.10.2021).

2. Законопроект № 1247642-7 «0 внесении изменений в статью 134 Трудового кодекса Российской Федерации (в части обязательств работодателей по индексации заработной платы работников)». URL: https://sozd.duma.gov.ru/bill/1247642-7 (дата обращения: 10.10.2021).

3. Законопроект № 1258295-7 «0 федеральном бюджете на 2022 год и на плановый период 2023 и 2024 годов». URL: https://sozd.duma.gov.ru/ bill/1258295-7 (дата обращения: 10.10.2021).

4. Определение ВС № 18-КГ17-10. URL: https://www.vsrf.ru/documents/practice/24411/ (дата обращения: 10.10.2021).

5. Определение Конституционного Суда РФ от 19 ноября 2015 г. № 2618-0. URL: https://www.garant.ru/products/ipo/prime/doc/71165798/ (дата 0бращения: 10.10.2021).

6. Определение СК по гражданским делам Верховного Суда РФ от 8 апреля 2019 г. N89-КГ18-14. URL: https://www.garant.ru/products/ipo/prime/ doc/72148062/ (дата обращения: 10.10.2021).

7. Петухова 0.А. Правовые пути решения проблемы своевременности индексации заработной платы в России // Теория и практика эффективности государственного и муниципального управления. Курск, 2021. С. 203-205.

8. Размеры минимальной заработной платы в субъектах Российской Федерации. URL: http://www.consultant.ru/document/cons_doc_LAW_291114/ (дата обращения: 10.10.2021).

9. Стоимость условного (минимального) набора продуктов питания. URL: https://www.fedstat.ru/indicator/31481(дата 0бращения: 10.10.2021).

10. Стоимость фиксированного набора потребительских товаров и услуг. URL: https://www.fedstat.ru/indicator/31052 (дата 0бращения: 10.10.2021).

( Куксин Иван Николаевич ( proffkuk-1944@уandex.ua ), Шухов Федор Гелиевич ( fedor.ru@bk.ru ).

Журнал «Современная наука: актуальные проблемы теории и практики»

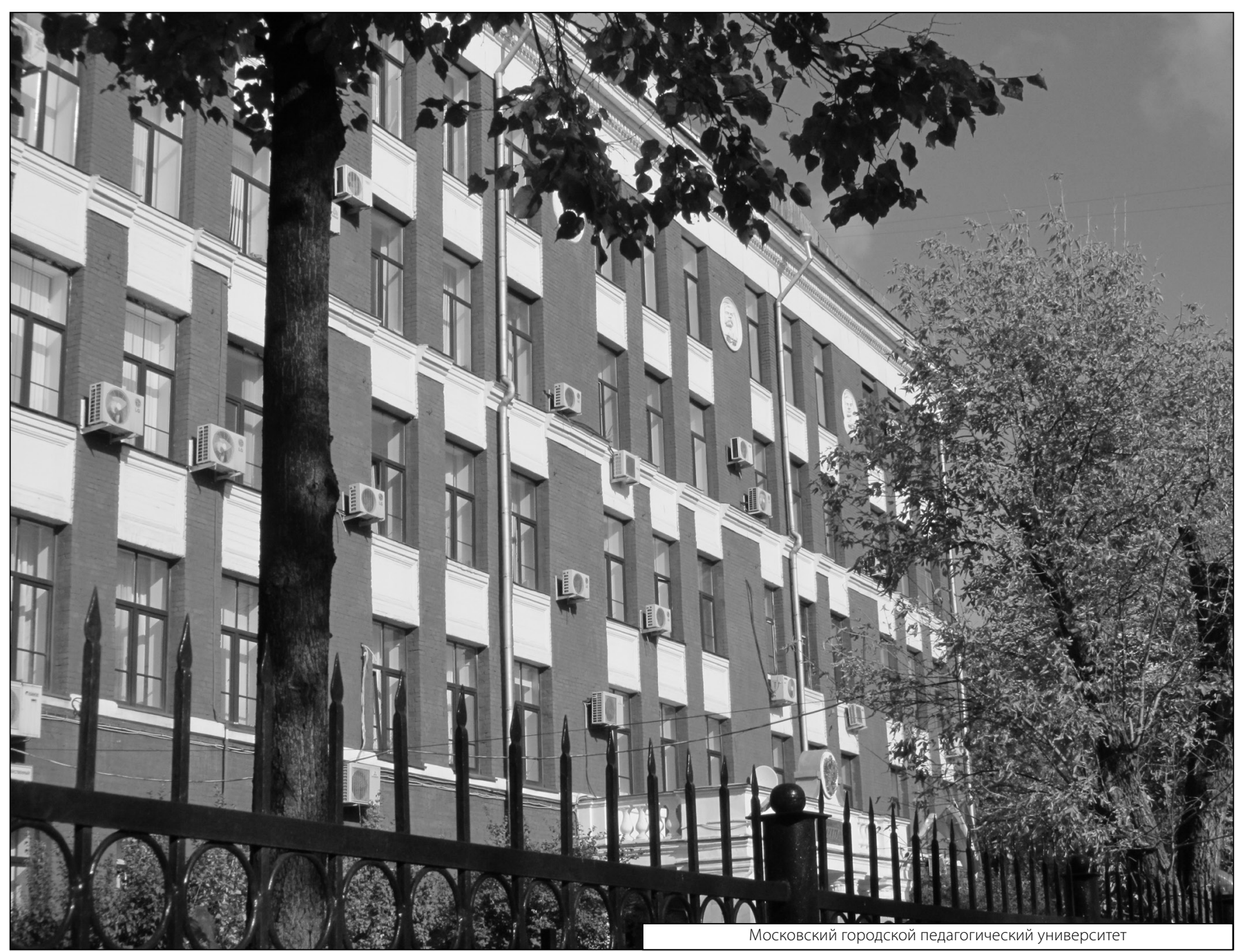

